УДК 551.89:551.797 (571.63)

ПОЗДНЯЯ ФАЗА АТЛАНТИЧЕСКОГО ПЕРИОДА ГОЛОЦЕНА НА ЮГЕ ПРИМОРЬЯ

\author{
Микишин Ю.А., Петренко Т.И., Гвоздева И.Г. \\ ФГБУН «Дальневосточный геологический институт» ДВО РАН, Владивосток, \\ e-mail: yurimikishin@fegi.ru
}

\begin{abstract}
На основе изучения новых, а также исследованных ранее разрезов голоценовых отложений на континентальной и островной частях южного Приморья восстановлена наиболее полная картина ландшафтноклиматических изменений в позднюю фазу атлантического периода голоцена. 1. 6800-6600 календарных лет назад: время первого относительного похолодания, близкого к современному климату. В растительном покрове преобладают широколиственные леса с преимуществом дуба. Хвойно-широколиственные леса играют небольшую роль в горах. 2. 6600-6400 л.н.: время оптимального, возможно максимального в голоцене, потепления климата. Развиваются дубово-грабовые леса. Участие граба (содержание пыльцы 20-25\%) в лесах островов шире, чем в континентальной растительности (9-16\%). 3. 6400-6300 л.н.: время второго относительного похолодания, вызвавшего резкое обеднение широколиственных лесов грабом, в меньшей степени ильмом и орехом. 4. 6300-6050 л.н.: время первого относительного потепления, с условиями прохладнее оптимальных, но существенно превышавших современные. Распространяются широколиственные леса с преобладанием дуба и большим участием граба, чаще встречающегося на островах. 5. 6050-5800 л.н.: время третьего, наиболее продолжительного относительного похолодания. Как и предыдущие похолодания, оно вызвало выпадение граба из состава широколиственных лесов. Хвойно-широколиственные леса сокращают до минимума своё участие в растительности гор. 6. 5800-5500 л.н.: время второго относительного потепления, превышавшего, возможно, уровень предыдущего. На островах развиваются дубово-грабовые леса, на континенте - широколиственные, с преобладанием дуба и большим участием граба. В горах восстанавливается прежняя небольшая роль хвойно-широколиственных лесов. 7. 5500-5300 л.н.: время третьего относительного потепления, бывшего прохладнее и, вероятно, намного влажнее предыдущего. В растительности южного Приморья появляются настоящие полидоминантные широколиственные леса, с близким участием дуба, ореха, ильма, граба, липы и сирени. В горах территории, впервые с середины атлантического периода голоцена, хвойно-широколиственные леса получают распространение, сопоставимое с их ролью в современном растительном покрове юга Приморья.
\end{abstract}

Ключевые слова: атлантический период голоцена, торфяник, спорово-пыльцевой комплекс, пыльца граба, дубово-грабовые леса, палеоландшафт, палеоклимат

\title{
LATE PHASE OF ATLANTIC PERIOD OF THE HOLOCENE IN SOUTHERN PRIMORYE (RUSSIAN FAR EAST)
}

\author{
Mikishin Yu.A., Petrenko T.I., Gvozdeva I.G.
}

Far East Geological Institute Far Eastern Branch RAS, Vladivostok, e-mail: yurimikishin@fegi.ru

Based on the study of new and previously studied Holocene sedimentary sections from the continental and island parts of the Southern Primorye, the most complete picture of landscape and-climatic changes during the late phase of the Atlantic Period of the Holocene was reconstructed. 1. 6800-6600 calendar years ago - the time of the first relative cooling, close to the modern climate. The vegetation cover is dominated by broad-leaved forests with prevalence of oak. Coniferous-broadleaved forests are unessential in the mountains. 2. 6600-6400 Cal. yr BP - the time of the optimal, possibly maximum, climate warming in the Holocene. Oak-hornbeam forests are developing. A hornbeam participation (pollen content is 20-25\%) in the forests of the islands is wider than in the continental vegetation (9-16\%). 3. 6400-6300 Cal. yr BP - the time of the second relative cooling, which caused a sharp depletion of broad-leaved forests with hornbeam, to a lesser extent elm and walnut. 4. 6300-6050 Cal. yr BP - the time of the first relative warming with conditions that are cooler than optimal but significantly exceeding modern ones. Broadleaved forests with oak predominance and a large participation of hornbeam, which is more common on the islands, are abundant. 5. 6050-5800 Cal. yr BP - the time of the third, the most prolonged relative cooling. As with the previous coolings, it caused the hornbeam disappearance from broadleaved forests. Coniferous-broadleaved forests minimize their participation in the vegetation of the mountains. 6. 5800-5500 Cal. yr BP - the time of the second relative warming, possibly exceeding the level of the previous one. Oak-hornbeam forests develop on the islands and broadleaved forests with oak predominance and a large participation of hornbeam are widespread on the continent. In the mountains, the original small state of coniferous-broadleaved forests is being restored. 7. 5500-5300 Cal. yr BP - the time of the third relative warming, which was cooler and probably much wetter than the previous one. In the vegetation of southern Primorye, the real polydominant broadleaved forests with close participation of oak, walnut, elm, hornbeam, linden and lilac appear. In the mountains of the territory, for the first time since the Middle of Atlantic Period of Holocene, coniferous-broadleaved forests are getting development comparable to their role in the modern vegetation cover of the Southern Primorye (Russian Far East).

Keywords: Atlantic Period of Holocene, peat-bog, pollen assemblage, hornbeam pollen, oak-hornbeam forests, paleolandscape, paleoclimate

Поздняя фаза атлантического периода (далее ПАТ), согласно схеме периодизации голоцена, модифицированной для Северной Евразии [1], продолжалась около 1500 лет, с 6000 радиоуглеродных лет назад (далее л.н.) до 4600 л.н. Приведение возрастных рамок к астрономическому возрасту определяет их в 6800-5300 календарных лет 
(далее к.л.н.). В начале этого времени, около 6000-5500 л.н. / 6800-6300 к.л.н., происходило одно из значительных потеплений климата, отнесённое к оптимуму голоцена во многих регионах Земли [2-4]. В Приморье оно подтверждено изучением обширного фактического материала в последней четверти прошлого века, и рассмотрено как часть всего послеледникового термического максимума, либо как второй климатический оптимум атлантического периода голоцена [5]. В растительности, согласно этим исследованиям, преобладали полидоминантные (применение этого термина к растительным группировкам с преобладанием одной породы, введённое в оборот в 1970-е гг. и до сих пор используемое многими авторами, крайне неудачно) широколиственные леса с преимуществом дуба и максимальным участием термофильных пород, таких как граб и орех (Juglans). Реже встречались орехово-дубовые леса с грабом и ясенем. Постоптимальное время ПАТ, около 5200-4500 л.н. / 6000-5000 к.л.н., отличалось похолоданием климата, отмеченным наступанием горных ледников в разных районах Земли [2]. Ландшафтноклиматические изменения этого времени в Приморье оставались слабо изученными, за исключением относительного похолодания около 5600-5400 л.н. [5].

Более поздние исследования, проведённые в 1998-2008 гг. [6], дали возможность подробнее рассмотреть историю природы юга Приморья в течение ПАТ. Было выявлено относительное похолодание, происходившее в начале фазы (6600-6450 к.л.н.), оптимальное потепление, при котором развивались дубово-грабовые леса - в середине (6450-6000 к.л.н.), относительное похолодание - в конце (6000-5500 к.л.н.), и потепление прохладнее оптимального на завершении атлантического периода (5500-5200 к.л.н.).

В дальнейшем, после изучения голоцена островных территорий, максимальное потепление было отнесено к завершающей стадии ПАТ, около 4750 л.н. / 5500 к.л.н. [7, 8]. Его хронология нарушала прежнюю схему палеоклиматических колебаний. Кроме того, возникла неопределённость в хронологии постоптимального похолодания, датированного на континентальной части южного Приморья концом ПАТ (5100 л.н. / 5800-5900 к.л.н.). На островах в одновозрастных отложениях был установлен спорово-пыльцевой комплекс (далее СПК), отразивший рас- тительность, развивавшуюся в климатических условиях намного теплее современных. Отмеченные несоответствия в хронологии и последовательности событий вызвали необходимость в дополнительном изучении коротко-периодичных изменений ПАТ южного Приморья. Важность его проведения подчёркивается небольшим прогрессом, достигнутым в решении этого вопроса в работах самых последних лет [9-12].

Цель исследования: уточнить характер, последовательность и геохронологию ландшафтно-климатических изменений на юге Приморья в течение ПАТ.

\section{Материалы и методы исследования}

Изучены отложения торфяников на о. Русский и в долине р. Рязановка (рис. 1), а также лагунно-морские осадки в долине р. Раздольной. Спорово-пыльцевым анализом исследовано 33 образца, в том числе 20 - из разреза «Пб-10», 10 из «Подножье-І» и 3 - из «Скв. Раздолье». Обработка проб выполнялась по стандартным методикам, с двукратным обогащением в тяжёлой калиево-кадмиевой жидкости. В каждом образце насчитывалось 600-1000 зёрен пыльцы и спор, из которых 300-500 принадлежит древесным растениям. В общем составе спорово-пыльцевых спектров участие групп пыльцы деревьев и кустарников, трав и кустарничков, a также спор устанавливалось от всего количества микрофоссилий. Содержание компонентов спектра подсчитывалось отдельно в группах пыльцы древесных пород, трав и кустарничков, а также спор. Реконструкция палеорастительности выполнена на результатах изучения субфоссильных СПК [13]. Теплообеспеченность палеоклиматических событий оценивалась количеством пыльцы теплолюбивого граба (Carpinus), повышенное присутствие которой в отложениях атлантического периода отмечено большинством исследователей голоцена Приморья [5-8, 10-12, 14]. За уровень, соответствующий современным климатическим условиям, принято максимальное количество (3-4\%) её пыльцы в субфоссильных спектрах. Фоссильные спорово-пыльцевые спектры с пиковым содержанием пыльцы граба свыше $10 \%$, наряду с преобладающим в них дубом, рассматриваются нами как отражение дубово-грабовых лесов, существовавших на юге Приморья в наиболее тёплые эпохи голоцена. 

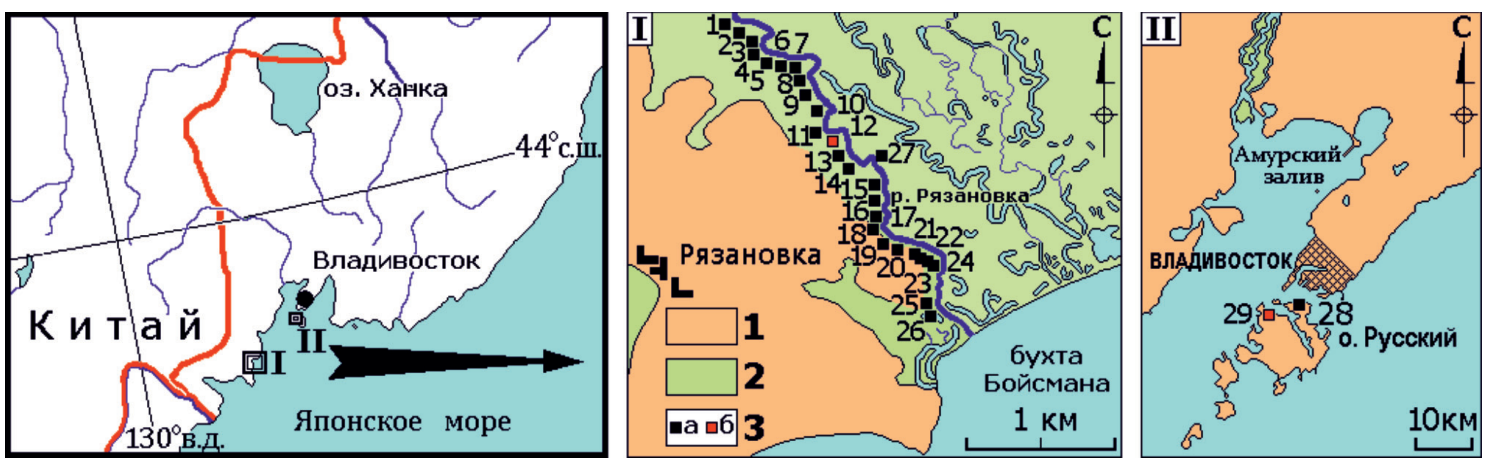

Рис. 1. Схема районов исследования.

1 - низкогорные массивы, 2 - низкие аккумулятивные террасы, 3 - разрезы голоиеновых отложений: $а$-изученные ранее [6, 8], б-рассмотренные в данной статье.

I- долина р. Рязановка: 1 - «Дорога», 2 - «Дорога-2», 3 - «Правый берег-036», 4- «Д-3», 5 - «Д-4», 6 - «Пб-б/2», 7 - «Пб-7», 8 - «Пб-8», 9- «Правый берег - 99», 10 - «Правый берег», 11 - «Пб-9»,

12 - «Пб-10», 13 - «Пб-5», $14-« П б-4 », 15-« П б-3 », 16-« П б-3 a », 17-« П б-2 a », 18-« П б-2 »$,

19 - «Пб-1», 20 - «Пб-15», 21 - «Мойка», 22 - «Мойка-2», 23 - «Пб-11», 24 - «Устричник-2»,

25 - «Скв. 3», 26 - «Скв. 4», 27 - «Левый берег». II - о. Русский: 28 - «Поспелово», 29 - «Подножье-І»

Абсолютный возраст отложений определялся в лабораториях палеоклиматологии кайнозоя Института геологии и минералогии СО РАН (8 радиоуглеродных дат, индекс СОАН), «Геоморфологические и палеогеографические исследования полярных регионов и Мирового океана» Института наук о Земле СПбГУ (2 даты, индекс ЛУ), а также «Paleo Labo Co., Ltd.», Сайтама, Япония (1 AMS-дата, индекс PLD). Стратиграфическое расчленение горизонтов, выделенных в разрезах, проведено в соответствии со схемой периодизации голоцена Блитта - Сернандера, модифицированной для Северной Евразии [1].

\section{Результаты исследования и их обсуждение}

На острове Русский болотные отложения стали накапливаться сразу после максимума послеледниковой трансгрессии Японского моря и поэтому распространены на побережье [8]. Одним из районов острова, где они слагают прибрежную террасу, является северный берег бухты Новик. Здесь изучен разрез торфяника «Подножье-І» $\left(43^{\circ} 02^{\prime} 46.1^{\prime \prime}\right.$ с.ш., $131^{\circ} 49^{\prime} 01.0^{\prime \prime}$ в.д.), лежащий западнее причала у одноимённого посёлка (рис. 1). В расчищенном уступе низкой аккумулятивной террасы (абс. высота около 1,5 м) на берегу моря вскрыты следующие отложения, в см:

- 0-7- супесь светло-серого цвета с корнями травы;
-7-30 - галечник из мелкой и средней гальки хорошей окатанности с супесчаным заполнителем светло-серого цвета;

-30-108 - торф, сильно разложившийся, чёрного цвета, с примесью песка, гравия и мелкой, хорошо окатанной гальки, в интервале 98-103 см - фрагментов стеблей тростника;

- 108-124 - торф низинный тростниковый плохо разложившийся, тёмно-бурого цвета, с включением средне-мелкозернистого песка;

- 124-129 - супесь серовато-коричневого цвета с тонкими прослоями суглинка мягкопластичной консистенции, с включением ризоидов мхов;

- 129-143 - гумусовый горизонт погребённой почвы - торф, сильно разложившийся, суглинистый, серовато-чёрного цвета;

- 143-146 - торф зостеровый (?) чёрного цвета, средней степени разложения;

- 146-206 - глина синевато-серого цвета с фрагментами стеблей трав и ризоидов мхов, включением щебня и плохо окатанной гальки алевролитов;

-206-230 - щебень крупный и плохо окатанная галька, с отдельной хорошо окатанной галькой и дресвой, с глинистым заполнителем светло-серого цвета.

На спорово-пыльцевой диаграмме отложений (представлены результаты изучения только нижней части разреза, в интервале $111-230$ см) выделяются следующие СПК (рис. 2). 


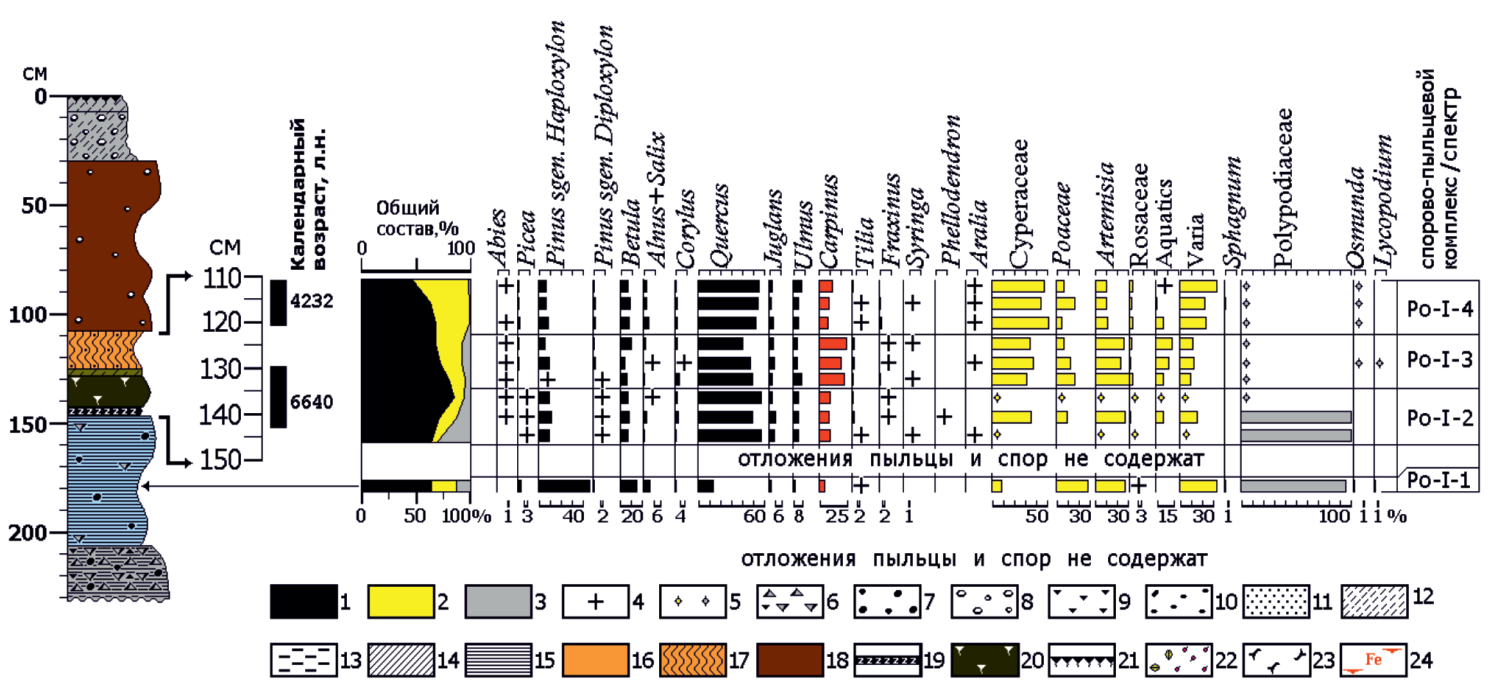

Рис. 2. Спорово-пыльцевая диаграмма отложений разреза «Подножье-І». Пыльия и споры: 1 - пыльцча деревьев и кустарников, 2 - пыльцฺа трав и кустарничков, 3 - cпоры, 4 - содержание пыльцы и спор менее 1\%, 5 -\% не подсчитан из-за малого числа обнаруженных зёрен пыльцы и спор. Литология: 6 -щеебень, 7 - галька плохо окатанная, 8 - галька хорошо окатанная, 9 - дресва, 10 - гравий, 11 -песок, 12 - супесь, 13 -алеврит, 14 - суглинок, 15 - глина, 16 - торф низинный, сильно разложсившийся, 17 - торф низинный тростниковый, 18 - торф верховой сильно- и среднеразложившийся, 19 - торф зостеровый (?), 20 - погребённая почва, 21 - дерновый горизонт современной почвы, 22 - орехи (Juglans mandshurica) и семена водных растений красного ивета, 23 -мелкие обломки древесины, 24 - ожелезнение

1. Делювиальные отложения в основании разреза пыльцы и спор не содержали. В перекрывающих их синевато-серых глинах (интервал 146-206 см), предположительно имеющих морской генезис (находки фауны и диатомей отсутствуют), пыльца и споры обнаружены лишь в пробе на глубине 179 см. Спорово-пыльцевой спектр (далее СПС) Po-I-1 имеет в общем составе лидерство пыльцы деревьев и кустарников (64\%). Среди неё преобладают хвойные породы, в основном кедр (сосна) корейский (Pinus koraiensis) - 47\% и ель $-3,5 \%$ ). Пыльца широколиственных деревьев, занимающая в спектре второе место, образована дубом (14\%), реже грабом $(4.7 \%)$, а также ильмом, орехом, лещиной и липой (до 2\%). Среди пыльцы мелколиственных пород больше берёз (15\%), чем ольхи (6\%). В группе пыльцы трав доминируют разнотравье (34\%), злаки (29\%) и полынь (27\%). СПС Ро-І-1 отразил развитие хвойно-широколиственных лесов. Близкие черты спектра и СПК Vn-2, из погребённой почвы в долине р. Виноградной с абсолютным возрастом около 6555 л.н. / 7470 к.л.н., СОАН-7181 [6], позволяют отнести его формирование к относительному похолоданию средней фазы атлантического периода голоцена.
2. Горизонт зостерового (?) торфа и нижняя часть гумусового слоя палеопочвы в основании торфяника (133-146 см) содержат СПК Ро-I-2. В общем составе комплекса, по сравнению с нижележащими отложениями, до 65-85\% повышается содержание пыльцы деревьев и кустарников, свидетельствуя об усилении роли лесов в растительности острова. В составе пыльцы древесных пород отмечается господство (76-81\%) широколиственных деревьев, с преимуществом дуба (50-58\%), реже граба (9-10\%), ореха (до 6\%), ильма (до $5 \%$ ) и липы (до $2 \%$ ). В незначительном количестве $(<1 \%)$ встречена пыльца ясеня, сирени, бархата и древесных пород семейства аралиевых. Пыльца хвойных пород, стоящая в комплексе на втором месте, образована кедром корейским (10-12\%), елью и пихтой (до 1\%). Мелколиственные породы представлены берёзами (7-8\%), реже - ольхой и ивами (до $3 \%$ ). Среди пыльцы трав преобладают осоковые (до 37\%) и полынь (до 27\%). Реже фиксируются разнотравье (до 16\%), злаковые (до $12 \%$ ) и водные растения (до 7\%). Споры образованы только папоротниками Polypodiaceae. CПК Ро-I-2 отвечает широколиственным лесам с преобладанием дуба и большим участием граба, а также хвойно-широколиственным ассоциациям - на ограниченных 
участках горных массивов острова. Климат был намного теплее и влажнее современного (содержание пыльцы граба в 2,2-3,3 раза превышает максимальные значения субфоссильных спектров). Абсолютный возраст потепления древнее 5800 л.н. / 6600 к.Л.н., поскольку дата (таблица, № 27) получена по отложениям погребённой почвы, перекрывающим горизонт зостерового (?) торфа. Поэтому обнаруженное событие мы связываем с потеплением в конце средней фазы атлантического периода голоцена, около 6200-5900 л.н. / 7100-6700 к.л.н. [6].

3. Верхняя часть гумусового горизонта палеопочвы и перекрывающая её супесь (124-133 см) содержат CПК Ро-I-3. В общем составе комплекса сохраняется лидирующая роль пыльцы деревьев и кустарников (70-80\%), среди которой происходит дальнейший рост доли широколиственных пород, достигающих максимальных значений (79-92\%). Ведущее значение дуба при этом несколько снижается (до 41-50\%), а граба, занимающего второе место, увеличивается до 20-25\%, что в 5-8 раз больше его максимального содержания в субфоссильных спектрах юга Приморья. Пыльца остальных широколиственных пород сохраняет прежние позиции. В то же время уменьшается участие пыльцы хвойных пород, в основном кедра корейского (до 6-10\%). Содержание других хвойных (ель, пихта, сосна Pinus subgen. Diploxylon) не превышает в сумме 3-4\%. Среди немногочисленной пыльцы мелколиственных пород больше берёз (4-9\%), чем ольхи. СПК Ро-І-2 отразил произрастание дубово-грабовых лесов, покрывавших большую часть о. Русский. Хвойно-широколиственные леса сохранились, вероятно, только на вершинных участках низкогорий острова. Столь термофильный характер растительности фиксирует наступление оптимальных климатических условий, превышавших уровень потепления средней фазы атлантического периода голоцена [6]. Абсолютный возраст оптимума около 5800 л.н. / 6600 к.Л.н. (таблица, № 27), что позволяет отнести его к началу ПАТ.

4. Слой низинного торфа в интервале 111-124 см содержит СПК Ро-I-3, общий состав которого отмечает падение количества пыльцы древесных пород (50-70\%) и рост травянистых растений (30-50\%). Эти изменения указывают на сокращение лесопокрытых площадей и расширение открытых пространств на острове. Среди древесной пыльцы доминируют широколиственные породы, с подросшей ролью дуба (52-54\%), и снизившейся, по сравнению с предыдущим комплексом, но ещё высокой долей граба (8-12\%). СПК Ро-I-3 отразил развитие дубово-грабовых лесов с меньшей встречаемостью граба, по сравнению с растительностью оптимума ПАТ, а также незначительное присутствие хвойно-широколиственной растительности на низкогорьях острова. Климат был прохладнее, чем в оптимальное время, но намного теплее и влажнее современных условий. Радиоуглеродная дата около 3800 л.н. / 4200 к.л.н. (таблица, № 26) указывает на принадлежность события к середине суббореального периода голоцена.

$B$ долине $p$. Рязановка отложения ПАТ широко представлены в чехле низкой аккумулятивной террасы (рис. 3). Среди них наибольший интерес для изучения динамики вековых ландшафтно-климатических изменений представляет слой низинного торфа, лежащий на глубине 2-2,7 м от поверхности террасы и прослеженный по правому берегу реки на расстоянии около 500 м [6]. В 1,5 км выше устья р. Рязановка, где его мощность достигает 40-42 см, изучен разрез «Пб-10» (42 ${ }^{\circ} 47^{\prime} 55.3^{\prime \prime}$ с.ш., $131^{\circ} 16^{\prime} 13.3^{\prime \prime}$ в.д.) (рис. 4). Сверху вниз в разрезе вскрываются следующие слои, в см:

- 0-20 - Песок мелкий жёлтого цвета;

- 20-80 - Торф сильно разложившийся, с корнями трав;

- 80-100 - Суглинок тёмно-серого цвета;

- 100-112 - Торф верховой средне разложившийся, черновато-бурого цвета;

-112-120 - Суглинок буровато-серого цвета;

- 120-145 - Алеврит песчанистый, голубовато-серого цвета;

- 145-160 - Гравий песчанистый ожелезнённый, ржаво-бурого цвета;

- 160-166 - Песок мелкий алевритовый, голубовато-серого цвета;

- 166-210 - Гравий мелкий ожелезнённый, ржаво-бурого цвета;

- 210-230 - Глина тёмно-серого цвета;

- 230-272 - Торф низинный сильно разложившийся, светло-коричневого цвета, с включением многочисленных мелких обломков древесины, маньчжурских орехов и мелких круглых семян красного цвета водных (?) растений. В интервале 258-272 см присутствуют тонкие (мощность 0,3-1 см) прослои алеврита светло-серого цвета, включения гравия и мелкой плохо окатанной гальки алевролитов;

- 272-277 - Гравий и щебень алевролитов, уплощённый, с песчано-глинистым заполнителем тёмно-серого цвета. 
Радиоуглеродные датировки образцов изученных отложений ПАТ

\begin{tabular}{|c|c|c|c|c|c|c|}
\hline \multirow{2}{*}{$\begin{array}{l}\text { № } \\
\Pi / \Pi\end{array}$} & \multirow{2}{*}{$\begin{array}{c}\text { Разрез, } \\
\text { координаты }\end{array}$} & \multirow[t]{2}{*}{ Лаб. № } & \multirow{2}{*}{$\begin{array}{c}\text { Глубина } \\
\text { отбора, см }\end{array}$} & \multirow[t]{2}{*}{ Материал } & \multicolumn{2}{|c|}{ Возраст образца } \\
\hline & & & & & $\begin{array}{c}\text { радиоуглерод- } \\
\text { ный, л.н. }\end{array}$ & $\begin{array}{c}\text { календарный, } \\
\text { к.л.н.* }\end{array}$ \\
\hline \multicolumn{7}{|c|}{ Долина р. Рязановка, лагунно-морские отложения } \\
\hline 1 & $\begin{array}{c}\text { «огребённый } \\
\text { устричник-II» [6] } \\
42^{\circ} 47^{\prime} 33.0^{\prime \prime} \text { с.Ш. } \\
131^{\circ} 16^{\prime} 40.1^{\prime \prime} \text { в.д. }\end{array}$ & COAH-4127 & $0-30$ & $\begin{array}{c}\text { раковины } \\
\text { моллюсков }\end{array}$ & $5575 \pm 80$ & $6006 \pm 107 * *$ \\
\hline 2 & $\begin{array}{l}\text { «Устричник-2» [6] } \\
42^{\circ} 477^{\prime} 33.0^{\prime \prime} \text { с.Ш. } \\
131^{\circ} 16^{\prime} 40.1^{\prime \prime} \text { в.д. } \\
\end{array}$ & COAH-5005 & $235-250$ & $\begin{array}{c}\text { раковины } \\
\text { моллюсков }\end{array}$ & $5835 \pm 115$ & $6235 \pm 141 * *$ \\
\hline 3 & $\begin{array}{l}\text { «Левый берег» [6] } \\
42^{\circ} 477^{\prime} 55.4^{\prime \prime} \text { с.Ш. } \\
131^{\circ} 16 ' 22.3^{\prime \prime} \text { в.д. }\end{array}$ & Tka-13011 & $306-315$ & $\begin{array}{l}\text { раститель- } \\
\text { ный детрит }\end{array}$ & $4810 \pm 70$ & $5533 \pm 72$ \\
\hline \multicolumn{7}{|c|}{ Долина р. Раздольной, лагунно-морские отложения } \\
\hline 4 & $\begin{array}{l}\text { «Скв. Раздолье» } \\
43^{\circ} 32^{\prime} 47.3^{\prime \prime} \text { с.ш. } \\
131^{\circ} 51^{\prime} 43.5^{\prime \prime} \text { в.д. }\end{array}$ & PLD-12623 & $1200-1255$ & $\begin{array}{l}\text { фрагменты } \\
\text { древесины }\end{array}$ & $6000 \pm 35$ & $6845 \pm 45$ \\
\hline \multicolumn{7}{|c|}{ Долина р. Рязановка, болотные отложения } \\
\hline 5 & $\begin{array}{c}\text { «Дорога» [6] } \\
42^{\circ} 48^{\prime} 22.4^{\prime \prime} \text { с.ш. } \\
131^{\circ} 15^{\prime} 44.1^{\prime \prime} \text { в.д. }\end{array}$ & COAH-5000 & $224-231$ & торф & $5150 \pm 50$ & $5881 \pm 85$ \\
\hline 6 & \multirow{2}{*}{$\begin{array}{c}\text { «Правый берег-99» [6] } \\
42^{\circ} 477^{\prime} 57.6^{\prime \prime} \text { с.ш. } \\
131^{\circ} 16^{\prime} 12.2^{\prime \prime} \text { в.д. }\end{array}$} & COAH-4144 & $215-220$ & торф & $4550 \pm 55$ & $5198 \pm 107$ \\
\hline 7 & & COAH-4145 & $245-250$ & торф & $5625 \pm 160$ & $6446 \pm 167$ \\
\hline 8 & $\begin{array}{c}\text { «Правый берег» [6] } \\
42^{\circ} 47^{\prime} 56.9^{\prime \prime} \text { с.ш. } \\
131^{\circ} 16^{\prime} 12.2^{\prime \prime} \text { в.д. }\end{array}$ & COAH-3938 & $190-200$ & торф & $5125 \pm 45$ & $5851 \pm 70$ \\
\hline 9 & \multirow{8}{*}{$\begin{array}{l}\text { «Пб-10» } \\
42^{\circ} 477^{\prime} 55.3^{\prime \prime} \text { с.ш., } \\
131^{\circ} 16^{\prime} 13.3^{\prime \prime} \text { в.д. }\end{array}$} & COAH-5011 & $230-234$ & торф & $4465 \pm 35$ & $5139 \pm 109$ \\
\hline 10 & & COAH-5012 & $236-238$ & торф & $4470 \pm 60$ & $5124 \pm 125$ \\
\hline 11 & & COAH-5013 & $242-244$ & торф & $4625 \pm 65$ & $5338 \pm 114$ \\
\hline 12 & & COAH-5014 & $250-252$ & торф & $4840 \pm 55$ & $5567 \pm 66$ \\
\hline 13 & & COAH-5015 & $258-260$ & торф & $4940 \pm 60$ & $5687 \pm 61$ \\
\hline 14 & & COAH-5016 & $264-266$ & торф & $5000 \pm 100$ & $5762 \pm 108$ \\
\hline 15 & & COAH-5017A & $266-268$ & торф & $5150 \pm 25$ & $5920 \pm 12$ \\
\hline 16 & & COAH-5017 & $268-272$ & торф & $5250 \pm 45$ & $6041 \pm 82$ \\
\hline 17 & \multirow{2}{*}{$\begin{array}{c}\text { «Пб-5» [6] } \\
42^{\circ} 477^{\prime} 53.2^{\prime \prime} \text { с.ш. } \\
131^{\circ} 16^{\prime} 17.8^{\prime \prime} \text { в.д. }\end{array}$} & COAH-5008 & $210-215$ & торф & $4295 \pm 70$ & $4861 \pm 107$ \\
\hline 18 & & COAH-5009 & $235-240$ & торф & $5325 \pm 80$ & $6112 \pm 99$ \\
\hline 19 & $\begin{array}{c}\text { «Пб-3» [6] } \\
42^{\circ} 477^{\prime} 51.1^{\prime \prime} \text { с.ш. } \\
131^{\circ} 1621.9^{\prime \prime} \text { в.д. }\end{array}$ & COAH-4993 & $222-230$ & торф & $4900 \pm 70$ & $5659 \pm 62$ \\
\hline \multicolumn{7}{|c|}{ долина р. Рязановка, озёрно-лагунные отложения } \\
\hline 20 & $\begin{array}{l}\text { «Дорога-2» [6] } \\
42^{\circ} 48 ' 22.4^{\prime \prime} \text { с.ш. } \\
131^{\circ} 15^{\prime} 44.1^{\prime \prime} \text { в.Д. }\end{array}$ & COAH-4995 & 220 & древесина & $4560 \pm 35$ & $5205 \pm 104$ \\
\hline 21 & $\begin{array}{c}\text { «равый берег 036» [6] } \\
42^{\circ} 48^{\prime} 21.9^{\prime \prime} \text { с.ш. } \\
131^{\circ} 15^{\prime} 49.4^{\prime \prime} \text { в.д. }\end{array}$ & COAH-6171 & 350 & древесина & $4740 \pm 90$ & $5462 \pm 105$ \\
\hline \multicolumn{7}{|c|}{ о. Русский, болотные отложения } \\
\hline 22 & \multirow{4}{*}{$\begin{array}{l}\text { «Поспелово» [8] } \\
43^{\circ} 03^{\prime} 32.3^{\prime \prime} \text { с.ш. } \\
131^{\circ} 53^{\prime} 16.8^{\prime \prime} \text { в.д. }\end{array}$} & COAH-7675 & $240-245$ & торф & $5355 \pm 85$ & $6137 \pm 108$ \\
\hline 23 & & COAH-7674 & $220-225$ & торф & $5105 \pm 75$ & $5841 \pm 82$ \\
\hline 24 & & COAH-7673 & $200-205$ & торф & $4750 \pm 80$ & $5467 \pm 102$ \\
\hline 25 & & COAH-7672 & $185-190$ & торф & $4725 \pm 80$ & $5457 \pm 101$ \\
\hline 26 & \multirow{2}{*}{$\begin{array}{c}\text { «Подножье-І» } \\
43^{\circ} 02^{\prime} 46.1^{\prime \prime} \text { с.ш. } \\
131^{\circ} 49^{\prime} 01.0^{\prime \prime} \text { в.Д. }\end{array}$} & ЛУ-7613 & $111-112$ & торф & $3820 \pm 80$ & $4232 \pm 125$ \\
\hline 27 & & ЛУ-7612 & $129-143$ & палеопочва & $5820 \pm 130$ & $6640 \pm 150$ \\
\hline
\end{tabular}

Примечание. *Калибровка дат выполнена в программе CalPal (http://www.calpal-online.de).

**Даты по образцам морского генезиса не калиброваны и указаны только с поправкой на эффект резервуара [6]. 


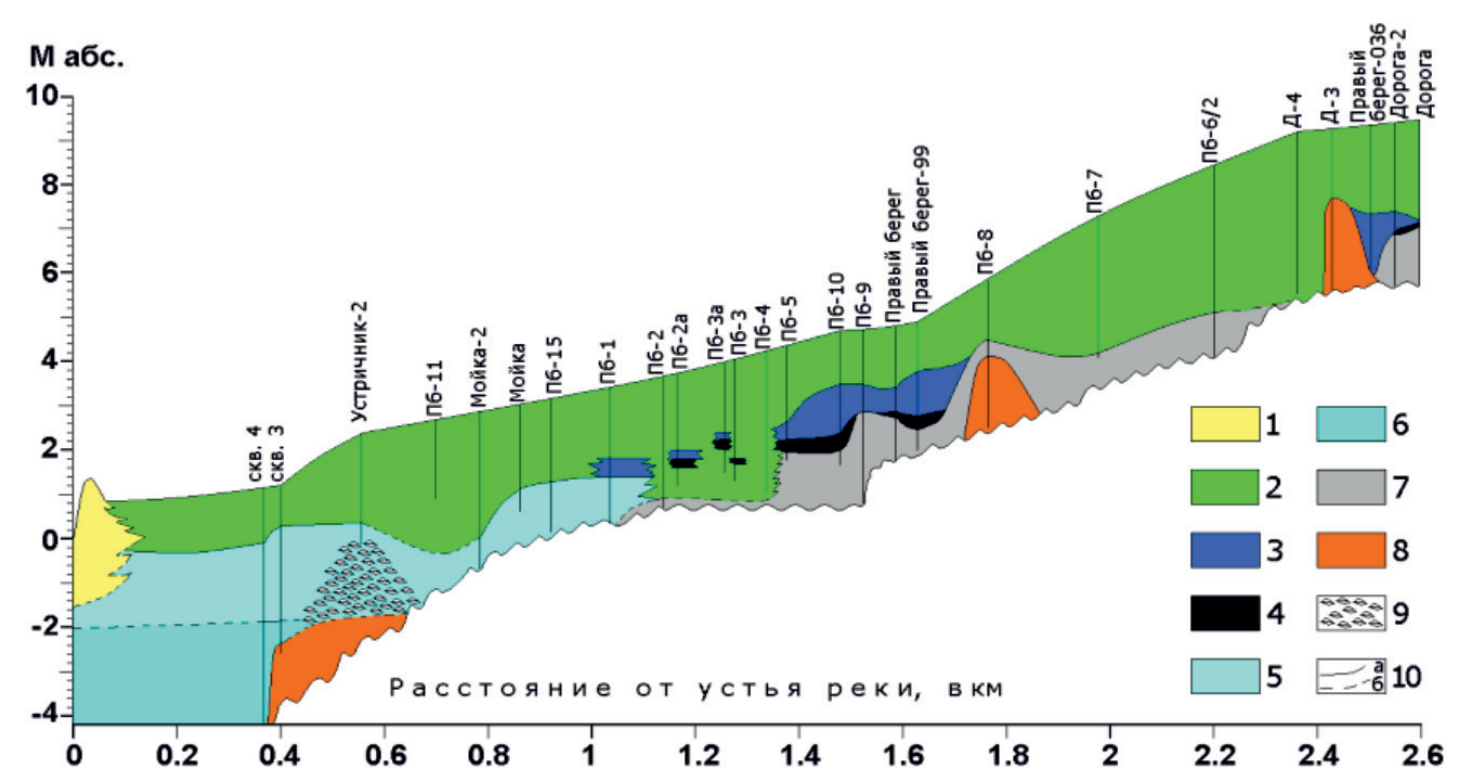

Рис. 3. Разрез голоченовых отложений низкой аккумулятивной террасы на правом берегу р. Рязановка. Современные отложения: 1 - морские волноприбойные. Отложения суббореального и субатлантического периодов голочена: 2 - аллювиальные и болотнье.

Отложения ПАТ: 3 - озёрно-лагунные, 4 - болотные, 5 -лагунно-морские.

Отложения средней фазы атлантического периода голочена: 6 - лагунно-морские. Отложения верхнего плейстоцена: 7 - озёрнье (12240 160 л.н. / $14400 \pm 390$ к.л.н., Тkа-13007), 8 - пролювиальные и элювиальные. 9 - скопления раковин тихоокеанской устрицы

(Crassostrea gigas), 10 - литологические гранищь: : - установленные, б - предполагаемые

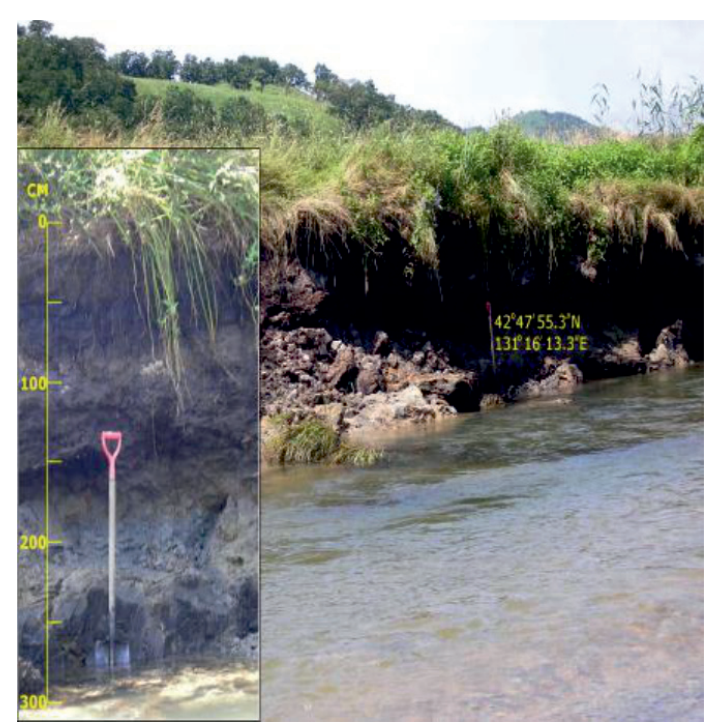

Рис. 4. Обнажение террасы в районе разреза «Пб-10»

На спорово-пыльцевой диаграмме (представлены результаты изучения только торфяных отложений, в интервале 230-272 см) выделяются следующие СПК (рис. 5).

1. Нижний горизонт, на глубине 264272 см, содержит комплекс Пб-10-1, отра- жающий распространение дубово-грабовых лесов и небольшую роль хвойно-широколиственной растительности. Комплекс формировался при оптимальных климатических условиях ПАТ. В его общем составе почти равное участие принимает пыльца древесных пород (41-54\%) и травянистых растений (39-50\%), что свидетельствует о близком соотношении площадей лесопокрытых и открытых территорий в бассейне р. Рязановка. Среди пыльцы деревьев и кустарников преобладают широколиственные породы с первенством дуба (27-32\%) и большим содержанием граба (9-12\%). Пыльца других широколиственных пород чаще представлена ильмом (5-8\%) и орехом (4-6\%), реже лещиной (до $3 \%$ ), липой, ясенем и сиренью (до $2 \%$ ). Изредка отмечаются бархат и аралиевые $(<1 \%)$. Мелколиственные деревья в большей степени образованы ольхой (20$31 \%$ ), чем берёзами (4-6\%). Пыльца хвойных пород представлена кедром (6-11\%) и незначительной долей пихты, ели и сосны (в сумме до 2\%). Среди пыльцы трав много осоковых (67-76\%), намного меньше разнотравья (13-17\%) и полыни (6-15\%). Споры образованы папоротниками Polypodiaceae (до 82\%) и Osmunda (до 22\%). 


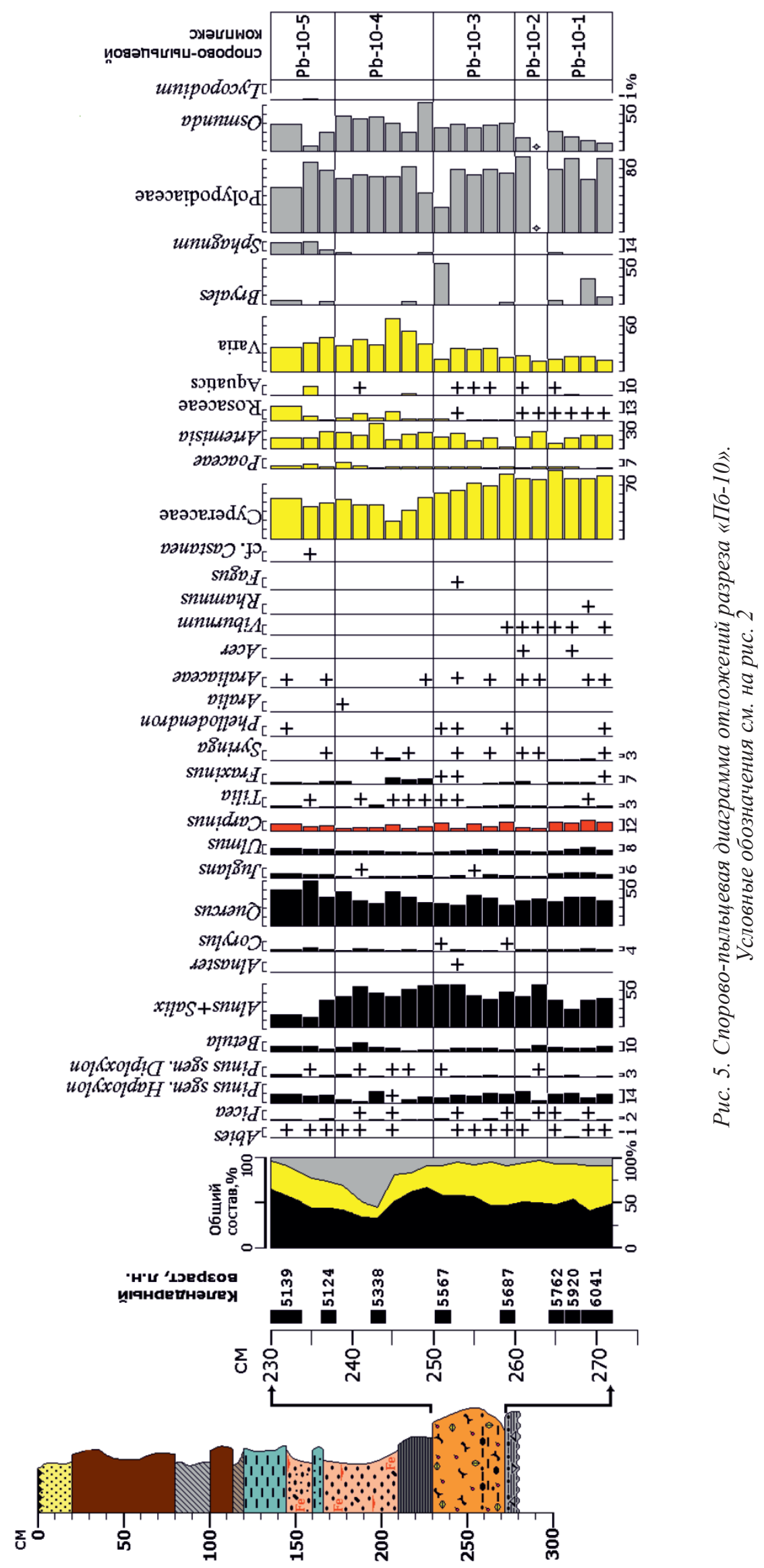


2. Маломощный горизонт торфа в интервале 260-264 смзаключает СПКПб-10-2. Он отвечает распространению широколиственных лесов с преобладанием дуба и небольшому участию хвойно-широколиственной растительности, развивавшихся при относительном похолодании климата. Среди пыльцы широколиственных пород, при сохранении прежнего значения дуба (28-30\%), происходит резкое, в 3 раза, падение роли граба $(3-4 \%)$ и сирени $(<1 \%)$. Также, до двух раз, уменьшается участие ильма (до 3-4\%) и ореха (2-3\%). Мелколиственные деревья по-прежнему чаще представлены ольхой (35-47\%), чем берёзами (до $7 \%$ ). Хвойные породы сохраняют прежнее значение, как и преимущество кедра (3-14\%), которое существенно ниже, чем в субфоссильных спектрах (26\%).

3. Слой торфа на глубине 250-260 см содержит СПК Пб-10-3, отразивший распространение широколиственных лесов с преобладанием дуба и большим участием граба, а также присутствие хвойно-широколиственных ассоциаций. Их развитие происходило в условиях намного теплее и влажнее современных, но уступавших оптимуму ПАТ. В общем составе комплекса наметилось усиление роли пыльцы древесных пород (48-57\%) над травами (35-44\%), свидетельствующее об увеличении площади лесопокрытых территорий. В группе пыльцы деревьев и кустарников основные изменения коснулись широколиственных пород. Позиции первенствующего среди них дуба несколько ослабли (с 31-34\% в нижней части слоя до 23-25\% - в верхней), а граба, напротив, укрепились до 8-10\%. В меньшей степени возросло содержание ильма (до 6\%), ореха (до 4\%) и липы (до $3 \%$ ). В группе пыльцы трав сократилось участие осоковых (51-74\%) и увеличилось - разнотравья (до 25-26\%). Среди спор, на фоне преобладания папоротников Polypodiaceae (28-70\%), до 30\% усиливается содержание папоротника Osmunda.

4. Торфяные отложения в интервале 238-250 см имеют СПК Пб-10-4, отвечающий широколиственным лесам с преобладанием дуба и хвойно-широколиственной растительности, до минимума сократившейся в горах территории. Их развитие протекало в условиях очередного, более продолжительного относительного похолодания, близкого к современному климату. В общем составе комплекса до 62-66\% возрастает участие древесных пород, что говорит о наибольшей облесённости тер- ритории. Среди пыльцы широколиственных пород усиливается роль дуба (25$38 \%$ ), и резко, в $1,5-3,4$ раза (до $3-5 \%$; $6,7 \%$ - только в одной пробе), снижается участие термофильного граба. Уменьшается также встречаемость ильма (до 2-4\%), opexa (1-3\%) и липы, при этом чаще фиксируются ясень (до 6-7\%), сирень и лещина (до $3 \%$ ). Участие пыльцы хвойных пород снижается до минимума. Преобладающий среди них кедр начинает встречаться в среднем в 2,5 раза реже (около $4 \%$ ), чем во время предыдущего события. В группе пыльцы трав произошло заметное ослабление роли осоковых (20-46\%) и возрастание разнотравья (28-59\%), полыни (10-27\%) и розоцветных (2-10\%). Споры отмечают дальнейший рост участия папоротника Osmunda (21-54\%).

5. Поверхностный горизонт (230238 см) торфа заключает СПК Пб-10-5, отразивший развитие широколиственных лесов с преобладанием дуба и большим участием граба, а также восстановление прежней, небольшой роли хвойно-широколиственных сообществ. Они формировались в условиях теплее современного климата, но уступавших оптимальным условиям начала ПАТ. Среди пыльцы древесных пород, первенствующей в комплексе, лидируют широколиственные деревья (53-72\%). Содержание многих из них, по сравнению с предыдущим событием, повышается: дуба - до 32-50\%, граба - до 5-8\%, ореха - до 4-5\%, ильма - до 6-7\% и лещины до 2-4\%. Возрастает и количество пыльцы хвойных пород (кедра) - до 10\%. В группе трав увеличивается значение розоцветных (до $13 \%$ ) и водных растений (до 10\%). Среди спор, на фоне преобладания папоротников Polypodiaceae (49-77\%), ослабевает роль Osmunda (6-29\%) и укрепляется - сфагновых мхов (5-14\%).

Для установления хронологии обнаруженных палеоклиматических событий проведено детальное радиоуглеродное датирование отложений. По образцам торфа была получена серия из 8 радиоуглеродных дат от 5325 л.н - в основании, до 4465 л.н. - в кровле слоя (таблица, № 9-16). Сравнение возраста верхнего горизонта торфа и перекрывающего его слоя озёрно-лагунных глин (№ 20, 21), показало, что нижележащие отложения моложе вышележащих на 90-275 лет. В соседних разрезах - «Правый берег-99» и «Пб-5» (рис. 3) - омоложение составляет соответственно 100-190 и 265-475 лет 
(№ 6, 17). Омоложение дат полученных по торфу, в отличие от древесных остатков, как доказано для болотных отложений Камчатки [15], может достигать 1-2 тысяч лет и вызываться, возможно, их длительной обводнённостью. Проявление этого эффекта позволяет сомневаться в корректности датировок не только верхнего, но и всех горизонтов слоя торфа в разрезе «Пб-10». Подтверждением этому служит явное несоответствие радиоуглеродного возраста (5250-5000 л.н. № 14-16) и термофильных спектров нижнего горизонта торфа, для которых ранее была получена дата около 5600 л.н. (№ 7). Поэтому для установления более точной хронологии событий использован расчёт возраста по скорости осадконакопления. Начало торфонакопления в разрезе «Пб-10» отнесено к 5800 л.н. (как установлено датированием оптимума ПАТ на Русском острове), окончание, согласно более древней дате по древесине из озёрно-лагунных осадков - к 4800 л.н. Средняя скорость торфонакопления, таким образом, составила 0,42 мм/год. Основываясь на ней, получаем следующие хронологические рамки обнаруженных событий: оптимальное потепление (СПК Пб-10-1) - 5800-5600 л.н., второе относительное похолодание - 56005500 л.н. (СПК Пб-10-2), первое относительное потепление (СПК Пб-10-3) 5500-5250 л.н., третье относительное похолодание - 5250-5000 л.н. (СПК Пб-10-4), второе относительное потепление (СПК Пб-10-5) - 5000-4800 л.н.

В долине р. Раздольной, на её правом берегу, ниже автомобильного моста у одноимённого посёлка изучены лагунно-морские осадки, вскрытые разрезом «Скв. Раздолье» (4332'47.3" с.ш., $131^{\circ} 51^{\prime} 43.5^{\prime \prime}$ в.д.). Основание разреза, представленное на глубине 12-12.55 м текучепластичными алевритами синевато-чёрного цвета, содержит CПК Rzd-1, имеющий почти полное сходство с СПК I-3, описанным из «Скв. 3» в интервале 170-200 см [6]. В общем составе комплекса преобладает пыльца деревьев и кустарников (62-64\%). Среди неё господствуют широколиственные породы с первенством дуба (30-36\%). Реже встречена пыльца ильма (13-14\%), ореха (3-9\%), граба (3-5\%), лещины (2-5\%), сирени, липы и ясеня (до 2\%). Присутствуют также бархат (Phellodendron), виноград, калина и аралиевые $(<1 \%)$. Мелколиственные породы, имеющие меньшую долю в комплексе, образованы пыльцой берёз (8-14\%), преобладающих над ольхой. Хвойные деревья представлены небольшим количеством пыльцы кедра корейского (7-13\%), ели, пихты и сосны (в сумме 4-5\%). СПК Rzd-1 отразил распространение широколиственных лесов с первенством дуба и небольшое развитие хвойношироколиственных ассоциаций в горах, прилегающих к долине р. Раздольной. Комплекс зафиксировал относительное похолодание климата в начале ПАТ около 6000 л.н. / 6800 к.л.н. (таблица, № 4).

\section{Заключение}

В результате изучения новых разрезов голоценовых отложений континентальной и островной частей южного Приморья, а также исследованных ранее [6, 8], наиболее полная картина ландшафтно-климатических изменений ПАТ выглядит следующим образом.

В начале фазы, около 6000-5800 л.н. / 6800-6600 к.л.н., происходило относительное похолодание, с параметрами, близкими к современному климату. В нижнем растительном ярусе территории преобладали многопородные широколиственные леса с преимуществом дуба. Хвойно-широколиственные леса имели небольшое распространение в горах. Вторая половина фазы, около 5800-5600 л.н. / 6600-6400 к.л.н., о3наменовалась оптимальным потеплением, достигавшим, возможно, максимального уровня в голоцене. В растительности преобладали дубово-грабовые леса, причём на островах участие граба в них было выше, чем на континентальной части южного Приморья. Климатические условия, возможно, были близки к современным на Корейском полуострове к югу от 39 с.ш. (среднегодовые температуры $10-12^{\circ} \mathrm{C}^{\circ}$, суммы осадков 1100-1600 мм), где растут дубово-широколиственные леса с различными видами граба, настоящий бамбук, магнолия и бензойное дерево. На завершении начальной стадии, около 5600-5500 л.н. / 6400-6300 к.л.н., произошло второе относительное похолодание ПАТ, зафиксированное выпадением граба, в меньшей степени ильма и ореха, из состава широколиственных лесов.

Середина фазы имела два события примерно равной продолжительности. Около 5500-5250 л.н. / 6300-6050 к.л.н. развивалось потепление с климатическими условиями прохладнее оптимальных, но существенно выше современных. В растительности вновь стали доминировать широколиствен- 
ные леса с преобладанием дуба и большим участием граба, чаще встречавшихся на островах. Затем, около 5250-5000 л.н. / 6050-5800 к.л.н., стало развиваться третье, наиболее продолжительное, относительное похолодание. В широколиственных лесах резко упала роль граба и до минимума сократилось участие хвойно-широколиственных ассоциаций в горах.

Завершаюшая часть фазы началась со второго относительного потепления, происходившего около 5000-4800 л.н. / 5800-5500 к.л.н. Его уровень, вероятно, превышал теплообеспеченность прежнего аналогичного термохрона, так как на островах в это время развивались дубово-грабовые леса [8]. На континентальной части росли широколиственные леса с преобладанием дуба и большой ролью граба. В горах сохранялись хвойно-широколиственные леса. Последнее событие, около 4800-4600 л.н. / 5500-5300 к.л.н., ознаменовалось появлением настоящих полидоминантных широколиственных лесов с близким участием дуба, ореха, ильма, граба, липы и сирени [6]. В горах хвойно-широколиственные леса укрепились и заняли позиции, сходные с их нынешним положением. Климат оставался теплее современного, хоть и прохладней, чем в начале завершающей части фазы. Влажность, возможно, превышала уровень всех палеоклиматических событий ПАТ.

Авторы выражают искреннюю благодарность А.Н. Попову, директору учебнонаучного музея ДВФУ, за большую помошь в проведении полевых работ.

\section{Список литературы / References}

1. Хотинский Н.А. Радиоуглеродная хронология и корреляция природных и антропогенных рубежей голоцена // Новые данные по геохронологии четвертичного периода. К XII конгрессу ИНКВА (Канада, 1987 г.). М.: Наука, 1987. C. 39-45.

Khotinsky N.A. Radiocarbon chronology and correlation of natural and anthropogenic boundaries of the Holocene// Novy`e danny`e po geoxronologii chetvertichnogo perioda. K XII kongressu INKVA (Kanada, 1987 g.). M.: Nauka, 1987. P. 39-45 (in Russian).

2. Борисова О.К. Ландшафтно-климатические изменения в голоцене // Известия РАН. Серия географическая. 2014. № 2. C. 5-20.

Borisova O.K. Landscape and climate changes in the Holocene// Izvestiya RAN. Seriya geograficheskaya. 2014 № 2. P. 5-20 (in Russian).

3. Razjigaeva, N.G., Ganzey L.A., Grebennikova T.A., Belyanina N.I., Mokhova L.M., Arslanov K.A., Chernov S.B. Holocene Climatic Changes and Vegetation Development in the Kuril Islands. Quaternary International. 2013. № 290-291. P. 126-138. DOI: 10.1016/j.quant.2012.06.034.

4. Igarashi Y. Holocene vegetation and climate on Hokkaido Island, northern Japan. Quaternary International. 2013. № 290-291. P. 139-150. DOI: 10.1016/j.quant.2012.09.030.
5. Короткий А.М. Палинологические характеристики и радиоуглеродные датировки верхнечетвертичных отложений Российского Дальнего Востока (низовье р. Амур, Приморье, о. Сахалин, Курильские острова)// Позднечетвертичные растительность и климаты Сибири и Дальнего Востока (палинологическая и радиоуглеродная база данных). Магадан: Изд-во Сев.-Вост. науч. центра ДВО РАН, 2002. C. $257-369$.

Korotky A.M., 2002. Pollen characteristics and radiocarbon dates of Last Quaternary deposits of Russian Far East (Lower Amur valley, Primorye, Sakhalin Island, Kuril Islands) // Pozdnechetvertichny`e rastitel 'nost` i klimaty` Sibiri i Dal’nego Vostoka (palinologicheskaya i radiouglerodnaya baza danny`x). Magadan: Izd-vo Sev.-Vost. nauch. centra DVO RAN, 2002. P. 257-369 (in Russian).

6. Микишин Ю.А., Петренко Т.И., Гвоздева И.Г., Попов А.Н., Кузьмин Я.В., Горбаренко С.А., Раков В.А. Голоцен побережья юго-западного Приморья // Научное обозрение. 2008. № 1. С. 8-27.

Mikishin Yu.A., Petrenko T.I., Gvozdeva I.G., Popov A.N., Kuzmin Y.V., Gorbarenko S.A., Rakov V.A. Holocene coast of southwestern Primorye // Nauchnoe obozrenie. 2008. № 1. P. 8-27 (in Russian)

7. Микишин Ю.А., Петренко Т.И., Гвоздева И.Г. Ландшафтно-климатические изменения в голоцене южного Приморья // VIII Всероссийское совещание по изучению четвертичного периода: «Фундаментальные проблемы квартера, итоги изучения и основные направления дальнейших исследований» (г. Ростов-на-Дону, 10-15 июня 2013 г.). Сб. статей. Ростов н/Д.: Изд. ЮНЦ РАН, 2013. С. 443-445.

Mikishin Yu.A., Petrenko T.I., Gvozdeva I.G. Landscape and climate changes in the Holocene of southern Primorye // VIII Vserossijskoe soveshhanie po izucheniyu chetvertichnogo perioda: «Fundamental`ny`e problemy` kvartera, itogi izucheniya i osnovny`e napravleniya dal'nejshix issledovanij» (g. Rostov-na-Donu, 10-15 iyunya 2013 g.). Sb. statej. Rostov n/D.: Izd. YuNCz RAN, 2013. P. 443-445 (in Russian).

8. Микишин Ю.А., Гвоздева И.Г. Палеосреда о. Русский (южное Приморье) в среднем-позднем голоцене // Фундаментальные исследования. 2014. № 3-3. С. 516-522.

Mikishin Yu.A., Gvozdeva I.G. Mid to Late Holocene of Russkyi Island (southern Primorye) // Fundamental research. 2014. № 3-3. P. 516-522 (in Russian).

9. Белянин П.С. Развитие геосистемы бассейна р. Бикин (Дальний Восток) в среднем и позднем голоцене // География и природные ресурсы. 2013. № 1. С. 105-111.

Belyanin P.S. Development of the geosystem of the river basin Bikin (Far East) in the Middle and Late Holocene // Geografiya i prirodny`e resursy`. 2013. № 1. P. 105-111 (in Russian).

10. Лящевская М.С. Ландшафтно-климатические изменения на островах залива Петра Великого (Японское море) за последние 20000 лет // Успехи современного естествознания. 2016. № 11-2. С. 372-379.

Lyashchevskaya M.S. Landscape and climate changes on the islands of Peter the Great Bay (Sea of Japan) over the past 20000 years // Advances in current natural sciences. 2016. № 11-2. P. 372-379 (in Russian).

11. Лящевская М.С., Макарова Т.Р., Разжигаева Н.Г., Ганзей Л.А., Кудрявцева Е.П., Паничев А.М., Арсланов Х.А., Максимов Ф.Е. Развитие ландшафтов полуострова Мурававьёва-Амурского в среднем-позднем голоцене по данным изучения отложений побережья бухты Муравьиной (Южное Приморье) // Успехи современного естествознания. 2017. № 2. C. 110-122.

Lyashchevskaya M.S., Makarova T.R., Razzhigaeva N.G., Ganzey L.A., Kudryavtseva E.P., Panichev A.M., Arslanov H.A., Maksimov F.E. The development of landscapes of the Muravyavyev-Amursky Peninsula in the Middle-Late Holocene according to the study of sediments of the coast of Muravyina Bay (Southern Primorye) // Advances in current natural sciences. 2017. № 2. P. 110-122 (in Russian).

12. Андерсон П.М., Белянин П.С., Белянина Н.И., Ложкин А.В. Эволюция растительного покрова западного по- 
бережья зал. Петра Великого в позднем плейстоцене-голоцене // Тихоокеанская геология. 2017. Т. 36. № 4. С. 99-108.

Anderson P.M., Belyanin P.S., Belyanina N.I., Lozhkin A.V. Evolution of vegetation cover of the west coast Peter the Great bay in the Late Pleistocene-Holocene // Tixookeanskaya geologiya. 2017. T. 36. № 4. P. 99-108 (in Russian).

13. Микишин Ю.А., Гвоздева И.Г., Петренко Т.И. Спорово-пыльцевые спектры современных отложений побережья юго-западного Приморья // Методические аспекты палинологии: Матер. Х Всерос. палинологической конф. М. ИГиРГИ, 2002. С. 154-156.

Mikishin Yu.A., Gvozdeva I.G., Petrenko T.I. Spore-pollen spectra of modern sediments of the coast of southwestern Primorye // Metodicheskie aspekty` palinologii: Mater. X Vseros. palinologicheskoj konf. M: IGiRGI, 2002. P. 154-156 (in Russian).
14. Караулова Л.П., Короткий А.М., Гвоздева И.Г. Пространственно-временная эволюция растительных сообществ голоцена на территории Приморья // Палинологические исследования на Дальнем Востоке. Матер. II межведомств. семинара по палинологическим исслед. Владивосток: ДВНЦ AH CCCP, 1978. C. 91-100.

Karaulova L.P., Korotky A.M., Gvozdeva I.G. Spatio-temporal evolution of Holocene plant communities in Primorye // Palinologicheskie issledovaniya na Dal'nem Vostoke. Mater. II mezhvedomstv. seminara po palinologicheskim issled. Vladivostok: DVNCz AN SSSR, 1978. P. 91-100 (in Russian).

15. Певзнер М.M. Голоценовый вулканизм Срединного хребта Камчатки. М.: ГЕОС, 2015. 246 с.

Pevzner M.M. Holocene volcanism of the Middle Ridge of Kamchatka. M.: GEOS, 2015. 246 p. (in Russian). 